\title{
Luottamus johtamisjärjestelmän uudistamisessa - Narratiivinen tapaustutkimus ei-henkilöityvän luottamuksen kehittymisestä vähittäiskaupan ketjuorganisaatiossa
}

\author{
Kirsti Malkamäki, Mirjami Ikonen \& Taina Savolainen
}

\begin{abstract}
Trust within the renewal of the management system - A narrative case study on impersonal trust development in retail chain organization
\end{abstract}

This article examines and illustrates understanding of the role of trust as intangible resource in organizational renewal. The qualitative case study was conducted in the retail organization undergoing a renewal process. In the prior organization research, trust is recognized supporting change implementation. The theoretical framework draws on the trust research of organizations. Trust is still scarcely studied as impersonal resource from the management system perspective. The data was gathered from managers and supervisors. The findings suggest a transparent management system as the basis of organizational trust. The study makes an interesting conclusion on the development of the nature of trust towards impersonal trust.

Keywords: Trust, transparency, change management, management system, renewal, control, retail

\section{JOHDANTO}

Luottamus on yhteistyötä ja kilpailukykyä vahvistava voimavara (McEvily ym. 2003, Burke ym. 2007, Savolainen 2011). Tutkimusten mukaan erot yritysten menestymisessä globaalissa talouselämässä ja kilpailutilanteissa voivat olla seurausta johdon kyvykkyydestä rakentaa luottamusta organisaatiossa (Fukuyama 1995; Bachmann 2011). Luottamus toimii yhteistyön liimana sekä muutosprosessin ajurina (BijlsmaFrankema 2001; Morgan \& Zeffane 2003; Sörensen ym. 2011) niin organisaation sisäisissä kuin organisaatioiden välisissä toimijasuhteissa eri yhteistyö- ja organisaatiotasoilla. Viime vuosikymmeninä luottamusta organisaatioissa on tutkittu paljon. Sen sijaan luottamuksen ja muutoksen välistä suhdetta on tutkittu pitkittäistutkimuksena niukasti, sillä muutoskirjallisuus käsittää valtaosin organisaatiotason tutkimuksia, kun taas luottamuskirjallisuudessa painottuvat henkilöidenvälisen luottamuksen tutkimukset (Sörensen ym. 2011).

Muutoksen johtaminen on haaste, johon johtajien on vastattava jatkuvasti kilpailutilanteiden ja toimintaympäristöjen muuttuessa. Uudelleen organisointi on usein keino, jolla kilpailukykyä pyritään vahvistamaan. Muutosten vaikutukset organisaatioissa ovat monitahoisia ja jännitteisiä, koska muutokset kohdistuvat valta- ja vastuusuhteiden sekä toimintatapojen uudelleen järjestämiseen. Siksi organisaatioissa on tullut yhä tärkeämmäksi tehtäväksi kehittää johtamista, sillä organisaation suorituskyky perustuu johtamisjärjestelmään ja johtamiseen, jonka perusteella luottamus rakentuu (Yukl 2010).

Uusimman tutkimustiedon mukaan luottamukseen voidaan vaikuttaa ja sitä voidaan tehokkaasti tukea makrotason institutionaalisilla, persoonattomilla organisaation rakenteellisilla tekijöillä ja menettelyillä (Bachmann 2011; Jagd \& Fuglsang 2016). Rakenteellisiin tekijöihin, kuten organisaatiorakenteeseen ja johtamiskäytäntöihin perustuva käyttäytymisen johtaminen 
luo kestävän perustan luottamukselle organisaatiossa (Whitener ym. 1998). Läpinäkyvä, suorituksen johtamista kuvaava tieto auttaa organisaation toimijoita - esimiehiä, alaisia, kollegoita - muuttamaan ja säätelemään käyttäytymistä (Kaptein 2008). Johdon tulisikin kiinnittää huomiota organisaatiorakenteeseen ja johtamiskäytäntöihin perustuvaan käyttäytymisen johtamiseen (Whitener ym.1998).

Tietoteknologia on tuonut uusia mahdollisuuksia ja samalla vaatinut sopeutumista uusiin johtamisen käytäntöihin (Malkamäki 2010; Savolainen 2014; 2016). Digitalisaatio mahdollistaa perinteisesti kankeina koettujen hierarkian ja valvonnan negatiivisten vaikutusten muuntamisen voimavaraksi tietotekniikkaa hyödyntävän johtamisen kautta. Kuitenkin sekä tutkimuksessa että yleisessä keskustelussa nostetaan toistuvasti esille luottamus johtamisen välineenä, jonka on katsottu joko kokonaan sulkevan pois tai vähentävän olennaisesti valvonnan tarvetta (Limerick \& Cunnington 1993). Toisaalta tutkimukset osoittavat, että asianmukaiset kontrollimenettelyt voivat itse asiassa lisätä luottamusta organisaatiossa, sillä formaalit kontrollimekanismit muodostavat kriteeristön ja perustan näytöille, joiden perusteella suoritusta arvioidaan (Goold \& Campbell 1987; Das \& Teng 2001; Sitkin \& George 2005). Luottamusta ja valvontaa ei siis nähdä toisiaan poissulkevina vaan päinvastoin vuorovaikutteisina keinoina organisaation johtamisessa ja tavoitteiden saavuttamisessa (Schoorman ym. 2007). Mölleringin (2005) mukaan yhteiskunnan ja organisaatioiden normisto ja rakenteelliset tekijät mahdollistavat luottamuksen sekä ohjauksen ja valvonnan myönteisen rinnakkaiselon, joka vahvistaa luottamusta organisaatioiden ja yksilöiden näkökulmasta.

Johdon tehtävä on varmistaa organisaation optimaalinen luottamus ja suorituskyky. Johdon tulee valita organisaation kontekstiin sopivat, tarkoituksenmukaiset toimintaa määrittävät ohjeistus- ja valvontamenettelyt. Valvontamenettelyitä tulee arvioida sekä vaihdella tilanteen ja asiayhteyden mukaan, sillä vahva valvontajärjestelmä voi estää luottamuksen kehittymistä. (Long \& Sitkin 2006.) Siksi on tärkeää tutkia ja nostaa esille johtamisjärjestelmään perustuvien johtamiskäytäntöjen - ohjeistuksen ja valvonnan (seurannan) - ja luottamuksen kaksinaisuus, niiden yhteen niveltyminen niin organisaatioyksiköiden kuin toimijoiden välisenä menettelynä erilaisissa yhteistyösuhteissa. Niinpä keskeinen johdon haaste on tehokkaan toiminnan edellyttämän päätöksenteon, koordinaation sekä luottamuksen ja seurannan yhteensovittaminen.

Organisaation johtamisjärjestelmä voi toimia ikään kuin kolmantena, ei-henkilöityvänä (impersonal) luottamusta vahvistavana tekijänä samalla tavoin kuin kolmas henkilö voi vahvistaa kahden toimijan välisen luottamuksen syntymistä (Bachmann 2011). Tällöin luottamus perustuu institutionaalisen järjestelmän (tässä johtamisjärjestelmän) määrittämään valtaan, oikeutuksiin ja rooleihin sekä sääntöihin ja normeihin, jotka ohjaavat suoritusta ja toimijoiden ennustettavaa käyttäytymistä.

Organisaatioissa tehdään jatkuvasti valta- ja vastuusuhteisiin sekä toimintatapoihin vaikuttavia muutoksia. Kun näitä rakenteellisia tekijöitä muutetaan, tarkastelun kohteena ovat kaikki organisaation hallussa olevat resurssit, kuten henkilöstö, vuorovaikutusmallit, tiedon hallinta sekä säännöt ja määritellyt rutiinit, jotka säätävät organisaation toiminnan yhtenäisyyttä (Rao ym. 2003). Tähän perustuen tässä tutkimuksessa luottamuksen kehittymistä tarkastellaan ei-henkilöityvänä ilmiönä vähittäistavarakaupan ketjuliiketoiminnan johtamisen kontekstissa, kun organisaation johtamisjärjestelmää uudistettiin merkittävästi.

Tämä artikkeli avaa johtamisjärjestelmän roolia ei-henkilöityvän luottamuksen rakentumisen perustana etsimällä vastausta tutkimuskysymykseen: Miten luottamus ilmenee ei-henkilöityvänä voimavarana organisaation johtamisjärjestelmän uudistamisessa? Mihin luottamuksen rakentuminen ja kehittyminen perustuvat? Tutkimus avaa luottamuksen sekä ohjauksen ja valvonnan linkittymistä toisiinsa luottamuksen rakentumisessa. Tämä mahdollistaa sen tarkastelun, kuinka luottaminen rakentuu organisaatiorakenteen ja hallinnollisten toimintamallien tuottamana ilmiönä. Tällöin hierarkkiset - sekä vertikaaliset että horisontaaliset - rakenteet ja johtamiskäytännöt synnyttävät luottamusta organisaatioon ja toimijoiden välille.

Vaikka luottamuksen hyödyt hyvän johtamisen tuloksena on tunnistettu, luottamusta on todettu olevan usein vaikeaa rakentaa ja ylläpitää 
(Kramer 1999). Ei siis ihme, että niin tutkijat kuin käytännön toimijat ovat kiinnostuneita tunnistamaan tekijöitä ja mekanismeja, joilla voitaisiin vaikuttaa luottamusta vahvistavaan johtamiseen ja johtajuuteen (esim. Gillespie \& Mann 2004). Tutkijoilla on tarve kysyä - ei ainoastaan luottavatko ihmiset toisiinsa ja missä määrin - vaan myös miksi ja millä perusteella (Dietz 2011, 220). Siksi on tärkeää tutkia, mikä on johtamisjärjestelmän merkitys luottamuksen rakentamisessa ja kehittymisessä (Malkamäki 2017).

\section{HENKILÖITYVÄ JA EI-HENKILÖITYVÄ LUOTTAMUS}

Luottamus on abstrakti, moniulotteinen ja dynaaminen ilmiö. Luottamuskirjallisuudessa tehdään ero henkilöityvän (mikrotaso) ja ei-henkilöityvän luottamuksen (makrotaso) välillä. Mikrotason luottamus viittaa henkilöiden väliseen, vuorovaikutuksessa syntyvään luottamukseen, kun taas makrotaso ei-henkilöityvään luottamukseen (Bachmann 2011; Welter 2012; Savolainen \& Ikonen 2016). Makrotason prosessit sekä rajoittavat että mahdollistavat mikrotason toimijasuhteita (Sitkin 1995; Rousseau ym. 1998). Luottamus voi olla myös mesotason käsite, joka yhdistää mikrotason psykologiset prosessit ja ryhmädynamiikan makrotason institutionaalisiin järjestelyihin (Brandsen \& Karre 2011). Mikro-, meso- (kollektiivinen) ja makrotasojen eroja on kuitenkin vaikea erottaa toisistaan selkeästi (Welter 2012).

Henkilökohtaiseen vuorovaikutukseen perustuva luottamuksen kehittyminen vaatii toistuvia suoria vuorovaikutuskontakteja (Ikonen 2015). Empiiriset tutkimukset kuitenkin osoittavat, että liiketoimintayhteyksissä on vain ajoittain tilaa henkilökohtaisiin suhteisiin perustuvalle luottamukselle (Bachmann 2011, 206). Organisaation koko, sekä sosiaalisesti ja rakenteellisesti hajallaan toimiminen eivät mahdollista henkilökohtaiseen tutustumiseen tarvittavaa aikaa ja kohtaamisia. Siten erityisesti suurissa organisaatioissa odotusten koordinointi vaatii institutionaalisia tekijöitä täydentämään henkilöidenvälistä vuorovaikutukseen perustuvaa luottamusta (Bachmann 2003). Digiaikana tämä henkilökohtaiseen vuorovaikutukseen perustuva puuttuva tieto voidaan osittain korvata (Zucker 1986; Creed \& Miles 1996; Malkamäki
2010; Savolainen 2014) esimerkiksi tietoteknisillä keinoilla. Siksi ei-henkilöityvä luottamus on nykyisenä tietoteknologian aikana elintärkeä luottamuksen muoto liiketoiminnassa (Giddens 1990; Bachmann 2011).

Ei-henkilöityvää luottamusta kuvataan termeillä systeemiluottamus ja institutionaalinen luottamus (Bachmann 2003). Systeemiluottamus viittaa luottamukseen, jossa rakenteelliset tekijät, kuten järjestelmät, menettelyt ja normit, ovat merkityksellisiä luottamusta rakentavia tekijöitä (Mäkipeska \& Niemelä 2005). Ajatuksena on, että määrättyjä käytäntöjä noudattamalla päästään parhaisiin tuloksiin (Sztompka 1999, 43-44). Siten organisaatiossa toimijan asemaan ja käskyvaltaan sekä teknisten järjestelmien toimivuuteen ja standardeihin perustuva luottamus on systeemiluottamusta. Institutionaalisen luottamuksen taustalla on luottamus siihen instituutioon, sosiaaliseen järjestelmään ja verkostoihin kokonaisuutena, jota yksilö edustaa (esim. Creed \& Miles 1996, 18; Lane 1998, 15-16; Ilmonen 2000, 22-23). Organisaatiossa tämä ilmenee jaettuina merkityksinä, mikä ohjaa käyttäytymistä ja muuntaa yksilötason päätöksenteon kollektiiviselle tasolle (Bachmann 2003).

Henkilöityvän ja ei-henkilöityvän luottamuksen raja organisaatioissa on kuitenkin häilyvä. Todellisissa työelämän arjen tilanteissa luottamus ilmenee henkilö- ja organisaatiotasoilla, jotka kietoutuvat toisiinsa erityyppisissä yhteistyösuhteissa (Das \& Teng 2001, 255; Burke ym. 2007, 610; Fulmer ja Gelfand 2012). Esimerkiksi työntekijöiden ja johdon välinen luottamus ei ole luonteeltaan henkilöityvää, vaan perustuu pohjimmiltaan rooleihin, sääntöihin ja rakenteisiin, jonka perusteella työntekijät arvioivat luottavatko johtoon vai eivät (Vanhala 2011). Henkilöiden välinen ja institutionaalinen luottamus siis ilmenevät yhtä aikaa (Dietz 2011, 199). Tämän lisäksi ne myös kehittyvät yhtä aikaa täydentäen ja korvaten toisiaan, mikä osoittaa luottamuksen kaksinaisen (duaalisen) ja dynaamisen luonteen (Welter 2012).

Tässä artikkelissa luottamusta tarkastellaan johtamisen välineenä henkilön personallisuuden ominaisuuksien sijaan. Tällöin jaettuja merkityksiä, kuten valtaa ja normeja, symboloidaan yhteistyössä toimintana ja käyttäytymisenä (Hardy ym. 1998, 70). Siten luottamus työyhteisössä perustuu jaettuihin merkityksiin, jotka 
ilmentyvät yhteistyössä roolin mukaisena toimintana ja käyttäytymisenä.

\section{JOHTAMISJÄRJESTELMÄ}

Johtamisjärjestelmä on organisaation johtamista määrittävä mekanismi, joka käsittää sekä johtamisen (management) että johtajuuden (leadership) osa-alueisiin liittyviä tekijöitä (Elsbach \& Kramer 1996; Yukl 2010). Johtamisjärjestelmä on johdon instrumentti, jolla ohjataan tavoitteiden asettamista ja saavuttamista sekä strategisella että operatiivisella tasolla. Se on yksi yrityksen strategisen johtamisen osa-alue, jonka pohjalta yritys suunnittelee, toteuttaa ja seuraa strategista toimintaansa (Kamensky 2008). Tätä täydentävät viestintä- ja vuorovaikutusmenettelyt, jotka tukevat johtajuuden osa-aluetta. $\mathrm{Ne}$ toimivat välineinä yhteisen ymmärryksen muodostamiseksi niin sähköisten menetelmien kuin kasvokkain kohtaamisten kautta.

Johtamisjärjestelmä kytkeytyy organisaatiorakenteeseen ja sen keskeisiin funktioihin, kuten työnjako (keskittäminen ja hajauttaminen), ohjaus ja raportointi sekä sääntöjen ja määräysten rooli toiminnassa. Toimiva ja tarkoituksenmukainen johtamisjärjestelmä muodostaa kokonaisuuden, joka käsittää organisaatiorakenteiden ja menettelyjen lisäksi toiminnallisesti asianmukaisia prosesseja ja mittareita sekä yrityksen arvot ja normit (Mitronen 2002, 409). Laamasen ja Tinnilän $(2009,113)$ mukaan johtamisjärjestelmä tarkoittaa "organisaation päämäärien saavuttamiseksi tarvittavaa organisaatiorakenteiden, toimintaperiaatteiden, menettelyiden, prosessien ja resurssien muodostamaa kokonaisuutta”. Tämä kokonaisuus muodostaa johtamiskäytännön, yrityksen tai organisaation johtamiskulttuurin (mts. 113).

Johtamisjärjestelmään sisältyy valvonnan, ohjauksen ja seurannan funktio. Valvonta on tehtäväkohtaisten tulosten mittaamista ja seurantaa, jonka tarkoitus on tähdätä tavoitteiden saavuttamiseen (Cardinal, Sitkin \& Long 2004). Perinteisesti valvonta liittyy keskitettyyn päätöksentekoon (Mintzberg 1979, 95), jolloin se on hierarkiaan perustuvaa vallankäyttöä oikeuttaen ja velvoittaen alaisten kontrollointiin. Hierarkiaan perustuva johtaminen saattaa johtaa organisaation jähmettymiseen ja sisäänpäin kääntymiseen asiakaslähtöisyyden sijaan, koska huomion kohteena on käyttäytyminen sääntöjen mukaan ja pelko sanktioista (Ouchi ja Maguire 1975, Laaksosen 2008 mukaan; Das \& Teng 2001, 259).

Perinteisistä johtamisen toiminnoista suunnittelu, organisointi ja ohjaus on nähty myönteisessä merkityksessä, kun taas valvonta mielletään yleensä kielteiseksi. Kuitenkin johtamismenettelynä valvonta on yksi keskeisistä johtamisen strategisista kysymyksistä (BijlsmaFrankema \& Koopman 2004). Siksi seurannassa on olennaista, että se kohdistuu strategian toteuttamisen kannalta keskeisiin elementteihin reaaliajassa. Tämä mahdollistaa korjaavat toimenpiteet oppimisen ja kehittämisen edellytyksenä tulevaisuutta varten (Kamensky 2008). Tästä näkökulmasta ohjaus- ja seurantamenettelyt ovat perustavia työvälineitä organisaatioiden johtamisessa (Cardinal, Sitkin \& Long 2004).

Johtamisjärjestelmä sisältää myös asiakkuuden johtamisen näkökulman. Ulkoisen asiakkaan saama tuote tai palvelu perustuu sisäiseen asiakkuuden johtamisen prosessiin, monivaiheiseen ja -tasoiseen yhteistyöhön organisaation sisällä. Tässä tutkimuksessa johtamisjärjestelmä nähdään Paynen ja Frow'n $(2005,173)$ sanoin ohjausmekanismina, jonka "keskeisenä tehtävänä on varmistaa strategian implementoinnin tarkoituksenmukainen ja standardien mukainen toiminnan taso, joka luo perustan toiminnan kehittämiselle".

\section{TUTKIMUKSEN TOTEUTTAMINEN}

Malkamäen (2017) tutkimuksen kohteena olivat toimijoille merkitykselliset johtamisjärjestelmään perustuvat johtamiskäytännöt, joita voidaan ymmärtää vain sosiaalisissa toimintaympäristöissä rakentuvien tarkoitusten tai merkitysten kautta (Berger \& Luckmann 1994; Eriksson \& Kovalainen 2016). Tavoite oli kuvata ja lisätä ymmärrystä tulkitsemalla syvällisesti ei-henkilöityvän luottamuksen kehittymistä tutkimuksen erityisessä kontekstissa.

Laadullisessa tutkimuksessa tutkija on vuorovaikutuksessa tiedonantajien kanssa ja siten osa tutkimuskenttää. Tutkimusten mukaan ihmisten tulkintojen ymmärtäminen edellyttää niiden tutkimista sellaisina, kuin yksilöt itse ovat ne kokeneet, mikä puolestaan edellyttää läheistä yhteyttä tutkittavien ja tutkijan välillä (Bogdan 
\& Biklen 1992, 33-35; Puusa \& Juuti 2011, 52). Tämän artikkelin ensimmäinen kirjoittaja on työskennellyt ennen tutkijaksi ryhtymistään huomattavan pitkän ajan kohdeorganisaatiossa. Tämän etuna voidaan mainita ensinnäkin pääsy organisaatioon, sekä ymmärrys toimijoiden eri rooleista ja toimenkuvista organisaatiomuutoksessa. Lisäksi organisaation tunteminen ja työkokemus auttoivat ymmärtämään organisaatiolle tunnusomaisia ilmaisuja, puhuttua kieltä ja kirjoitettua tekstiä. Toisaalta tuttu organisaatio loi myös tarpeen tiedostaa koko tutkimusprosessin ajan tutkijan oman subjektiivisuuden ja esiymmärryksen merkitys kysymyksissä, tulkinnassa, analysoinnissa ja raporteissa. Siksi aineistoa hankittiin sekä haastattelemalla että pyytämällä kirjoitettuja kertomuksia.

Laadullisen tutkimuksen arviointi kohdistuu koko tutkimusprosessin luotettavuuteen. Sisällönanalyysiin perustuvan luokittelun ja luottamustutkimuksen käsitteisiin perustuvan teemoittelun avulla on pyritty aikaansaamaan luotettava analyysi ja sulkemaan tutkija ulkopuolelle niin hyvin kuin se on mahdollista. Pätevyys voidaan laadullisessa tutkimuksessa ymmärtää uskottavuudeksi (credibility), mikä tarkoittaa aineiston ja havaintojen kuvaamista sekä tulkintojen ja johtopäätösten johdonmukaisuutta (koherenssi) suhteessa kuvaukseen. Vahvistettavuutta kuvaa se, kuinka hyvin tutkijan konstruktiot vastaavat tutkittavien tuottamia, ja kuinka hyvin tutkija tuottaa nämä konstruktiot ymmärrettäviksi myös muille lukijoille (Eskola \& Suoranta 2008; Eriksson \& Kovalainen 2016).

Aineistosta tehtyjen johtopäätösten loogisuus ja johdonmukaisuus on pyritty varmistamaan ottamalla varsin paljon suoria sitaatteja tulkintojen perustaksi. Näin lukija voi itse verifioida tutkijoiden päätelmät ja arvioida, päätyisikö hän sitaattien pohjalta samoihin tulkintoihin. Edellisen lisäksi kokemusmaailmojen yhtenevyyttä osoittaa se, pystyvätkö tutkimukseen osallistuneet toimijat ja myös muut organisaation toimijat kokemaan tutkijan tulkinnat ja raportoinnin omakohtaisiksi. Tähän perustuen kahdella tutkimukseen osallistuneella henkilöllä oli mahdollisuus antaa palautetta ja kommentoida tutkijan tulkintoja ja johtopäätöksiä. Face-validiteettia eli tuloksen esittämistä niille henkilöille, joita aineisto koskee, ei tässä tutkimuksessa kuitenkaan systemaattisesti käytetty.
Tutkimukseen (Malkamäki 2017) valittiin organisaation toimijoita, jotka ovat avainhenkilöitä johtamisjärjestelmään perustuvassa toiminnan johtamisessa. Täten tutkimusaineistoa tuottivat ketjuyksikössä ja tavarataloyksikössä keskijohdossa eri toimenkuvissa toimivat esimiehet ja asiantuntijat sekä asiakasrajapinnassa työnjohtotasolla toimivat esimiehet (Malkamäki 2010; Malkamäki 2017). Tutkimukseen osallistui 19 henkilöä, joista viisi henkilöä tuotti aineistoa kahteen eri otteeseen, joko haastatteluina tai kirjallisesti. Täten tutkimusaineisto koostuu haastatteluista (14) ja kirjallisista kertomuksista (10), sekä organisaation dokumenteista. Aineisto on kerätty useassa eri vaiheessa väitöskirjatutkimusta (Malkamäki 2017) varten. Ensimmäistä vaihetta kuvataan implementointivaiheeksi (2009-2010), sillä aineisto on kerätty noin vuosi johtamisjärjestelmän käyttöönoton jälkeen. Johtamisjärjestelmän vakiinnuttamisen vaihetta kuvataan termillä vahvistamisvaihe (toukokuu 2012 - maaliskuu 2013). Aineiston retrospektiiviset, avoimet haastattelut (2014) kohdistuvat aikakauteen 2009-2013. Yhteensä litteroitua haastattelu- ja kirjallista kertomusaineistoa kertyi 221 sivua.

Ensimmäisessä analyysivaiheessa runsas aineisto pelkistettiin jatkokäsittelyä varten teemoittelemalla. Sisällönanalyysi aloitettiin luokittelemalla haastattelu- ja tekstiaineistot teemoihin johtaminen, luottamus ja valvonta johtamisjärjestelmän rakenteellisen näkökulman mukaisesti. Seuraavaksi aineisto luokiteltiin organisaatio- ja toimijatasoittain. Esimerkiksi luottamus-teeman sisältä Malkamäki (2017) nosti esiin alateemat 1) kun puhuttiin luottamuksesta johtoon tai yleisesti luottamuksesta organisaatiossa tai 2) kun puhuttiin luottamuksesta henkilötasolla toisen yksikön toimijaan, kollegaan, esimieheen tai alaiseen. Edelleen aineisto analysoitiin rakenteellisten tekijöiden ja sosiaalisessa vuorovaikutuksessa syntyvien teemojen mukaan: roolit, menettelyt, viestintä- ja vuorovaikutusmenettelyt sekä valvonta ja mittaaminen (Malkamäki 2017).

Tässä artikkelissa keskitymme toimijoiden yhteistyössä syntyviin kokemuksiin ja käsityksiin luottamuksesta, joka ei selkeästi henkilöidy vaan kohdistuu esimerkiksi kollektiivisesti organisaation johtoon, toimijoiden välisiin suhteisiin tai esimieskunnan toimintaan yleisesti. 
Tutkimustulokset raportoidaan narratiivista analyysiä hyödyntäen. Narratiivisen tutkimuksen lähtökohtana on kuvata todellista elämää kokonaisvaltaisesti (Eriksson \& Kovalainen 2016). Pitkittäisaineisto mahdollisti muutoksen narratiivisen analyysin, joka kuvaa organisaation toimijoiden omia ajatuksia ja kokemuksia sekä käsityksiä tapahtumista kyseisessä kontekstissa, ei niinkään sitä mitä aktuaalisesti, tosiasiassa tapahtui (Riessman 1993). Aineisto on tulkittu tapaustutkimukselle ominaisesti hakien ymmärrystä tapauksen erityisestä kontekstista. Tulkintamme tueksi esitämme valitsemiamme aineistositaatteja, joiden viitteinä käytämme väitöskirjatutkimuksessa informanteille annettuja peitenimiä, kuten Maria, Amanda, jne. (Malkamäki 2017). Seuraava narratiivinen analyysi etenee lähtötilanteesta (2009) implementointivaiheeseen (2009-2010), ja tätä seuraavaan vahvistamisvaiheeseen (2012-2013). Lähtötilanteen kuvaus on työstetty yhteistyössä tutkimukseen osallistuneiden organisaation toimijoiden kanssa.

\section{EI -HENKILÖITYVÄN LUOTTAMUKSEN KEHITTYMINEN JOHTAMISJÄRJESTELMÄN UUDISTAMISEN PROSESSISSA}

\section{Lähtötilanteen kuvaus}

Tapausorganisaatio on vähittäistavarakaupan alalla toimiva ketjuorganisaatio, joka muodostuu ketjuyksiköstä ja tavarataloyksiköstä (kaupan toimijat). Ketjuyksikköön kuuluva hankintayksikkö vastaa ketjun tuotevalikoiman muodostamisesta, tuotteiden hinnoittelusta sekä markkinoinnista. Siten hankintayksikkö on merkittävässä roolissa ketjutason myynnin ja tuloksen tekemisessä.

Lähtötilanteessa, ennen johtamisjärjestelmän uudistamista, toiminnallisten organisaatioyksiköiden, hankintayksikön ja tavarataloyksikön, tehtäväjako oli päälinjoiltaan selkeä, vaikka hankintayksikön ja tavarataloyksikön välistä työnjakoa ei ollut yksityiskohtaisesi määritelty ja rajattu. Toiminnallisten organisaatioyksiköiden toimijat tekivät yhteistyötä erilaisissa suunnitteluryhmissä, joihin kaupan toimijat kutsuttiin tuloksen tekemisen taitoa osoittavien numeeristen faktatietojen perusteella. Siten päätöksenteko oli käytännössä osittain jaettua. Tämä toiminta- malli muodosti eräänlaisen piilo-organisaation, kun osa kaupan toimijoista toimi oman työnsä ohessa asiantuntijoina erilaisissa ketjun työryhmissä.

Organisaatiossa vallitsi vahva, vuosikymmenten aikana muodostunut yrittäjähenkinen yrityskulttuuri. Organisaation toimintakulttuuria luonnehti tulosjohtajuus. Ketjun johdon johtamisote oli vahvasti myyntihakuinen ja nopeasti uusia suuntia hakeva muun muassa toimitusjohtajavaihdosten vuoksi. Myös kentällä (tavarataloissa) myynnin ja tuloksen tekeminen koettiin kunnia-asiaksi. Tulosvastuullisten johto- ja päällikköasemissa toimivien toimijoiden näytöt ja suorituskyky perustuivat henkilökohtaiseen tavoitehakuisuuteen ja kompetenssiin sekä hyviin kollegiaalisiin suhteisiin. Kirjoittamaton ohje oli "saat tehdä melkein mitä vaan, kunhan onnistut". Tämä kannusti oma-aloitteisuuteen sekä samalla antoi epävirallisen valtuutuksen itsenäiseen päätöksentekoon ja toimintaan.

Ketjuohjauksesta huolimatta kentällä koettiin, että "olimme" vahvasti mukana päätöksenteossa. Tosiasiallinen toimintavapaus - päätöksenteko ja budjetointi oman vastuualueen osalta - olikin melko laajaa vielä vuosituhannen vaihteeseen saakka. Parhaiden käytäntöjen läpivienti ketjutasolla oli kuitenkin vaihtelevaa, koska operatiivista toiminnan johtamista ei ohjattu ja valvottu systemaattisesti. Tämän seurauksena sekä hankintayksikössä että tavarataloissa toiminnalliset vaihteluvälit ja sen myötä tuloksen vaihteluvälit olivat suuria, mikä ei vahvistanut luottamusta toimijoiden ja organisaatioyksiköiden välillä.

\section{Johtamisjärjestelmän uudistaminen}

Johtamisjärjestelmä uudistettiin vuonna 2009. Uusi johtamisjärjestelmä esiteltiin ketjukokouksessa ja otettiin käyttöön välittömästi. Johtamisjärjestelmän uudistuksen tavoitteena oli organisaation parempi suorituskyky ja luottamus organisaatiossa. Sörensen ym. (2011) mukaan muutoksessa luottamuksen vahvistaminen vaatii johdon vahvoja toimia ja keinoja, jotka viestittävät luottamuksenarvoisuuden ulottuvuuksia, kuten kyvyykyyttä, hyväntahtoisuutta ja integriteettiä.

Malkamäen (2017) tutkimuksessa johtamisjärjestelmän uudistuksen fokus oli ensinnäkin hankinta- ja tavarataloyksiköiden työnjaon ja 


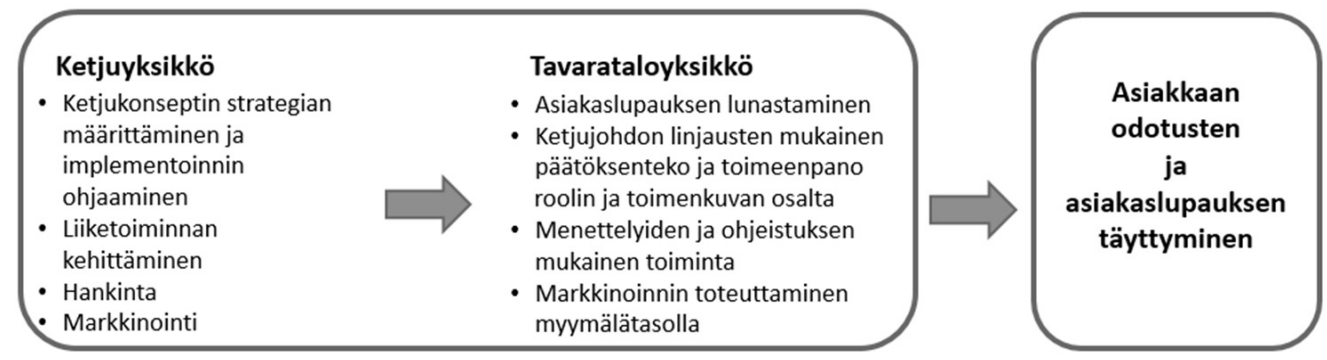

Kuvio 1. Liiketoiminnan prosessijohtamisen malli ja asiakkuuden johtaminen kohdeorganisaatiossa horisontaalisesti (Malkamäki 2017, 73)

yhteistyömenettelyiden selkeässä määrittämisessä. Tämä tarkoitti kaupan toimijoiden autonomian vähentämistä. Toiseksi, ketjuyksikön liiketoiminnan kehitysyksikön toimesta strategian läpiviennin kannalta olennaiset operatiivisen toiminnan johtamista ohjaavat menettelyt kirjattiin. Lisäksi tavoitteiden, ohjeistuksen ja menettelyiden mukaista toimintaa ruvettiin valvomaan systemaattisesti. Edelleen, vahvistamisvaiheessa suunnittelu ja päätöksenteko keskitettiin kokonaisvaltaisesti ketjuyksikköön samalla kun ohjeistusta ja valvontaa tarkennettiin.

Kuviossa 1. kuvataan organisaation liiketoiminnan prosessijohtamisen malliin perustuva asiakkuuden johtaminen horisontaalisesti. Uudistuksen jälkeen myynnin ja tuloksen tekemisen vastuu keskitettiin hankintayksikköön. Tavaratalojen vastuulle määriteltiin asiakaslupauksen lunastaminen ketjuyksikön linjausten ja dokumentoitujen menettelyiden mukaisesti. Alla olevassa kuviossa kuvataan ainoastaan organisaation hankinta-, liiketoiminnan kehitys- ja tavarataloyksiköiden rooli asiakkuuden johtamisen prosessissa, sillä näiden yksiköiden rooli muuttui johtamisjärjestelmän uudistuksessa merkittävästi.

\section{Työnjako organisaatiossa}

Uuden johtamisjärjestelmän myötä implementointivaiheessa vastuualueet rajattiin selkeästi. Tämän koettiin tuovan selkeyttä vastuualueisiin ja antavan oikeutuksen oman toimenkuvan mukaisten tehtävien hoitamiseen. Myös Whitener ym. (1998) mukaan rakenteellisiin tekijöihin, kuten organisaatiorakenteeseen ja johtamiskäytäntöihin perustuva käyttäytymisen johtaminen luo kestävän perustan luottamukselle organisaa- tiossa. Tämä todentui, kun organisaatioyksiköiden ja toimijoiden suorituksen johtaminen perustuivat yhdenmukaiseen tietoon ja ymmärrykseen eri toimenkuvien vastuualueista, odotuksista, oikeuksista ja velvollisuuksista sekä päätöksentekomenettelyistä. Aiemmin hankinta- ja tavarataloyksiköiden välistä työnjakoa ja päätöksentekomenettelyitä ei ollut rajattu ja määritelty selkeästi, vaan tuotevalikoimiin liittyviä päätöksiä oli tehty erilaisissa yhteistyöfoorumeissa ja sähköisesti viestimällä. Kuten hankintayksikön toimija Maria totesi:

Nyt on luotu selkeet raamit tekemiselle. Ja se helpottaa silloin kaikkee tekemistä, valintojen tekemistä ihan kaikkee, kun sull on on sanottu, minkä äärellä sä voit olla ja minkä äärellä sä et oo tai sun ei tartte olla. --- Meiän vastuulla on tuottaa ne työkalut siihen, että se johtaminen on siellä (kaupoissa) tehokasta ja se tuottaa hyvää asiakassuhdetta ja palvelua.

Tavaratalossa toimivan osastopäällikön mukaan johtamisjärjestelmä raamittaa ja roolittaa organisaatioyksiköiden ja eri toimenkuvissa toimivien organisaation toimijoiden välistä yhteistyötä. Tällöin eri yhteistyötahot voivat luottaa siihen, että toimijat eri yksiköissä ja eri organisaatiotasoilla johtavat ja toimivat oman roolinsa ja toimenkuvansa odotusten mukaisesti:

Mitä enemmän toimijoita niin sen tärkeämpää, et kaikki pystyy luottamaan et jokainen tekee siinä roolissa sen tehtävänsä. ... Jos ei organisaation eri tasot ja osat pysty luottamaan toisiinsa, se yleensä kertoo siitä, et se kehikko missä toimitaan - oli se sit johtamismallin tai järjestelmän nimellä - että se on 
hapero. Et ihmiset ei tiedä paikkaansa ja mitä heiltä odotetaan. (Osastopäällikkö Helmi)

\section{Menettelyt ja ohjeistus}

Määriteltyjen menettelyiden dokumentointi paransi viestinnän yksiselitteisyyttä ja ymmärrettävyyttä sekä loi määritellyille menettelyille sopimusluonteisen painoarvon. Läpinäkyvät johtamismenettelyt, kuten tiedonjakamisen avoimuus, paransivat organisaation sisäisten sidosryhmien luottamusta organisaatioon (Avolio, Kahai \& Dodge 2001; Schnackenberg \& Tomlinson 2014, 19). Läpinäkyvyyden myötä jokainen saattoi luottaa, että odotukset olivat yhdenmukaiset, rooliin ja toimenkuvaan perustuvat, kuten Amanda hankinnasta kuvasi:

Et nyt on tullu paljon uusia ja tarkkojakin menettelyitä siitä, että miten asioita tehdään ja johdetaan sillai systemaattisesti ja tietyllä toimintaperiaatteella, mitkä on kirjattuna ja ne on kaikille nähtävissä ja ne on selkeitä. Jokainen ymmärtää sen oman roolinsa.

\section{Läpinäkyvyys, tavoitteet ja mittaaminen}

Uuden johtamisjärjestelmän käyttöönoton yhteydessä otettiin toimintamalliksi kokonaisvaltainen läpinäkyvyys mittaamisessa. Näin sekä tavoitteet että suorituksesta kertova data olivat nähtävissä sisäisessä verkossa. Läpinäkyvä, suorituksen johtamista kuvaava tieto oli peruste muuttaa ja säädellä käyttäytymistä (Kaptein 2008). Samalla läpinkyvyys mahdollisti esimiestoimijoiden keskinäisen seurannan kaikilla organisaatiotasoilla sekä myös yksiköiden välillä. Läpinäkyvyys koettiin johtamisen tukipilarina, joka samalla oikeutti ja velvoitti toimimaan asetettujen tavoitteiden mukaisesti.

Tietysti siellä on nyt se organisoituminen tapahtunu niin, et siel on selkeesti ne vastuualueet, tavoitteet ja se mittaaminen, niin sekin on läpinäkyvää. Et me voidaan myös kaupan toiminnoissa nähdä, ett ei pelkästään meidän luvut, vaan se näkyy sitten tuota hankinnan ... niinku vastuuhenkilöittäin, näkyy heidän vastuualueet, ett miten he on suhtees tavoitteeseen. --- Ja tarkottaa sitä, että kun meillä on tämmönen tehotoimisto, joka on järjestelmä tuolla, jonne kaikki asiat sitten niinku talo- ja osastotasollakin, tietyt asiat tallennetaan, niin ne on sieltä kenen tahansa alkaen toimitusjohtajasta päälliköihin asti mahdollisuus kattoa, ja pääsee kattomaan myöskin, että miten jossain toisessa talossa tai toisella osastolla toimitaan. (Aluejohtaja Onni)

Johtoasemassa toimivan ketjuyksikön toimijan mukaan johtamisen systematiikka perustuu johtamisjärjestelmään. Johtamisjärjestelmä käsittää tavoitteet, raportit sekä valvontamenettelyt, jotka ovat toiminnan johtamisen työvälineitä. Kun toiminnan johtaminen perustuu ketjutasolla määriteltyihin toimintamalleihin ja kriteereihin, luo se perustan ja oikeutuksen aseman ja toimenkuvan mukaiselle esimiestyölle ja suorituksen johtamiselle. Kuten hankintayksikön Maria kuvasi:

Jotta sä voit johtaa niin sulla pitää olla ne systeemit ja siihen sitten tehtynä ne valvontamenetelmät. --- Lähtökohtaisesti se lähtee siitä, että on se johtamismalli, on ne systeemit ja ne paikat, että sä voit kattoo, että tarviiko puuttua tai ei tarvi puuttuu ja miten sinä sitä valvot.

Uuden johtamisjärjestelmän lanseeraustilaisuudessa esiteltiin uusi mittaristo, jota oli uudistettu kentän palautteen pohjalta. Sörensen ym. (2011) ovatkin todenneet, että luottamuksen korjaamisen keinoja ovat johdon vahvat toimet, jotka viestittävät luottamuksenarvoisuuden ulottuvuuksia (kyvykkyys, hyväntahtoisuus ja rehellisyys). Tavaratalojohtajan mukaan mittaristo ja toiminnallista tulosta kuvaavat tunnusluvut, jotka olivat toimijoiden vertailun perusteita, koettiin nyt oikeudenmukaisiksi. Aikaisemmin tämä tunnusluku sisälsi merkittävän kustannuserän, johon toimijat eivät voineet vaikuttaa. Oikeudenmukainen mittaaminen synnytti luottamusta johtoon ja motivoi parempiin suorituksiin, kuten tavaratalojohtaja asiaa kommentoi:

Kerrankin mittari, jossa mitataan, verrataan katteeseen ja sitten se, että sieltä on jätetty ne vuokrat pois. Sit on niinkö se, ett --- sieltä on poistettu se, mihin me ei voida vaikuttaa. Ja se motivoi mua aivan älyttömästi. Lisää te- 
kemään tämän homman eteen, et mä haluan näyttää, että kyllä määkin pystyn tekemään tulosta. Kyllähän mä oon se tienny aina, mutta kun me on ketjussa vedetty aina se tilasto, jossa on ne vuokrat. (Tavaratalojohtaja Juhani)

\section{Standardit - vaatimustaso ja tehokkuus}

Ketjutoiminnan idea on yhdenmukainen ja tasalaatuinen suoritustaso. Tämän tarkoitus on taata yritykselle kilpailukykyä ja asiakkaalle yhdenmukainen, tasalaatuinen asiakaspalvelu ja asiointikokemus asiakasrajapinnassa. Toimijoiden käsityksissä tämä ilmeni ketjuyksikössä toimivan Eliaksen sanoin:

Mikä on olennaista ketjutoiminnassa, pyritään vaihtelua minimoimaan. Elikä, miten saadaan suoritus mahdollisimman tasalaatuiseksi riippumatta siitä, onko siellä Liisa vai Matti hommissa, niin se suoritus on samanlainen.

Määritellyt menettelyt velvoittivat, mutta samalla ne myös viestivät yhdenmukaisista odotuksista, sillä menettelyt tuli ymmärtää sääntöinä, jotka koskettivat jokaista. Esimiestoimijat ja koko henkilökunta saattoivat luottaa siihen, että toiminnan johtaminen perustuu ketjumääritysten mukaiseen määriteltyyn vaatimustasoon - ei yksittäisen lähiesimiehen näkemykseen, kunnianhimoisiin tavoitteisiin tai mielipiteeseen.

Et tietyl tavallahan me samalla puhutaan vaatimustasosta. Koska näähän on kirjallisesti kuvattuja asioita kuinka tulee toimia, niin se on se vaatimustaso, johon jokaisen pitää päästä. Ja silloin jokainen voi luottaa siihen, että se koskee myös häntä ja tuota ja sitä. Ja se rakentaa sitä luottamusta. (Aluejohtaja Johannes)

Johtamisjärjestelmän nähtiin tässä vaiheessa tuottavan luottamusta niin organisaatiotason näkökulmasta kuin esimies-alaissuhteessa. Sverdrupin ja Stensakerin (2017) mukaan muutoskirjallisuus on osoittanut, että luottamuksella on myönteisiä vaikutuksia muutosprosessin alussa, mutta se joutuu myöhemmin koetukselle ja usein horjuu muutosprosessin edetessä (myös esim. Morgan \& Zeffane 2003).

Nyt toimintatavat ja keinot ovat säädeltyjä. Luottamus on kollektiivista roolin mukaista tehtävien hoitamista niin suhteessa organisaatioon kuin esimies-alaissuhteissa. Tavallaan, se asettaa niinku sellaset raamit. Mutta, jos sinä sitä luottamuksen kannalta ajattelet, niin sehän synnyttää sitten luottamusta ihan väkisin, eihän siinä ole kuin yks vaihtoehto. Ja, sitten jokaisen on päätettävä voiko toimia siinä vai ei. (Osastopäällikkö Helmi)

\section{Valvonta muutoksen ja suorituksen johtamisessa}

Vahvan yrityskulttuurin muuttaminen vaati vahvaa muutoksen johtamista, mikä tapausorganisaatiossa tarkoitti ketjutason ohjeistusta ja seurantamenettelyä. Ketjun ohjeistuksesta huolimatta kaikki johtoasemissa toimineet esimiehet eivät aikaisemmin olleet kykeneviä kohtelemaan lähialaisiaan yhdenmukaisesti, mikä heijastui työyhteisön yhteishenkeen. Nyt läpinäkyvyys ja valvonta asettivat paineita yhdenmukaiseen ja yhdenvertaisuuden periaatteeseen perustuvaan johtamiseen, jotka osastopäällikkö Helmi näki muutoksen johtamista ja yrityskulttuurin muutosta tukevina voimina:

Ja se, että vaikka on johtamisjärjestelmä tai tavat toimia, niin jos ei niitä valvota, niin nää sitkeimmät tyypit tekee ihan miten ite lystää. Ja sitten mua ainakin henkilökohtaisesti nyppi aika monta kertaa ja kohtuullisen katkerasti se, --- jos siinä omassa toimipisteessä tai talossa esimerkiksi osa vaan ei tee sillai kuin tää johtamisjärjestelmä. Ja jos sitä ei valvottais, niin sehän olis edelleen se vanha yrityskulttuuri.

Vahvistamisvaiheessa (2011) johtamisjärjestelmään perustuvaa ketjuyksikön valta-asemaa tavarataloyksikköön nähden vahvistettiin. Ketjuyksikköön perustettiin liiketoiminnan kehitysyksikkö, jonka tehtävä oli määrittää ja kuvata suorituksen johtamisen mittaristoa ja johtamismenettelyitä. Siten ketjujohto toimi julkaisemansa strategian mukaisesti. 


\section{TULOSTEN YHTEENVETO}

Tässä tapaustutkimuksessa kuvataan luottamuksen kehittymistä ei-henkilöityvänä ilmiönä ketjuliiketoiminnan johtamisen kontekstissa kaupan alan organisaation johtamisjärjestelmän uudistamisen implementointi- ja vahvistamisvaiheissa. Tutkimus avaa johtamisjärjestelmän roolia ei-henkilöityvän luottamuksen rakentumisen perustana valaisten sitä, kuinka luottaminen rakentuu organisaation rakenteiden, menettelyiden ja operatiivisen johtamisen tuottamana ilmiönä.

Tapaustutkimuksen lähtötilanteessa (Taulukko 1) eli aikakautena ennen uutta johtamisjärjestelmää, johtamista ja luottamusta luonnehti tulosjohtajuus ja henkilöiden välinen tuntemiseen ja kokemukseen perustuva luottamus. Johdon ja esimieskunnan johtamisotetta kuvasi myynti- ja tuloshakuisuus, joka perustui vahvasti yksilöiden kompetenssiin sekä hyviin kollegiaalisiin suhteisiin, ei niinkään vahvaan ketjuohjaukseen ja seurantaan. Työnjako hankintayksikön ja kaupan toimijoiden välillä ei ollut selkeästi rajattua, joten käytännössä päätöksen tekeminen oli osittain jaettua. Lisäksi osa kaupan toimijoista toimi oman työnsä ohessa asiantuntijoina erilaisissa työryhmissä, mikä muodosti eräänlaisen piilo-organisaation. Parhaiden käytäntöjen läpivienti ketjutasolla oli vaihtelevaa, sillä tarkkaa ketjutason kirjallista ohjeistusta ja toimeksipanon valvontaa ei ollut. Dokumentoinnin ja seurannan puutteesta seurasi merkittäviäkin toiminnallisia vaihteluvälejä niin hankintayksikössä kuin tavarataloissa. Tämä vaikutti yksiköiden toimijoiden toistensa luottamuksenarvoisuuden arviointiin, erityisesti kompetenssin ja suunnitelmallisuuden osalta.

Uudistetun johtamisjärjestelmän implementointivaiheessa (2009-2010) luottamus organisaatiossa vahvistui. Merkittävä rakenteellinen uudistus oli hankinta- ja tavarataloyksiköiden selkeä työnjako ja tähän perustuvat oikeudet ja velvollisuudet. Johtamisjärjestelmän selkeys oli vahva perusta luottamuksen rakentumisessa toiminnallisten organisaatioyksiköiden välillä. Myös Mäkipeska ja Niemelä (2005) toteavat, että toimintakulttuuria kehitettäessä organisaatiotason rakenne ja johtamisjärjestelmä antavat lähtökohdan luottamusta vahvistavalle toiminnalle.

Ketjuliiketoiminnan johtaminen systemati- soitui ja yhdenmukaistui. Tämä paransi ja vahvisti sekä toiminnallisten organisaatioyksiköiden että toimijoiden välistä keskinäistä luottamusta. Luottamuksen rakentumista tukivat yhdenmukaiset odotukset, läpinäkyvyys ja valvonta, jotka koettiin ennustettavuutta, tasapuolisuutta ja oikeudenmukaisuutta vahvistavina tekijöinä. Uudistettu, relevantti mittaristo sekä sähköisten viestintä- ja vuorovaikutuskanavien kehittäminen vahvistivat luottamusta organisaatiossa sekä synnyttivät toiminnan kehittämisen kulttuuria.

Ohjaus- ja seurantamenettelyiden nähtiin tuottavan tasalaatuisuutta ja yhdenmukaisuutta toimintaan, mikä paransi suorituskykyä. Siten tämän tutkimusartikkelin mukaan valvonta voi saada positiivisia merkityksiä silloin, kun se parantaa ennustettavuutta ja koettua oikeudenmukaisuuden tunnetta organisaatiossa. Luottamuksen ja valvonnan positiivinen yhteisvaikutus, tehokkuutta ja yhdenmukaisuutta aikaansaavana kaksinaisuutena (Möllering 2005) toteutui implementointivaiheessa.

Vahvistamisvaiheessa (2011-2013) ohjausta ja valvontaa lisättiin. Samalla johtamisjärjestelmä toimi vahvana esimiestyön tukielementtinä, joka oikeutti ja velvoitti määrämuotoiseen suorituksen johtamiseen. Kurinalainen johtamismenettely yhdenmukaisti käyttäytymistä ja toiminnan johtamista. Etenkin tavarataloyksikön toimijoiden puheissa korostui ketjun johtamisjärjestelmään perustuva odotus määrämuotoisesta, roolin ja toimenkuvan mukaisesta suorituksesta. Johdon näkökulmasta tämä synnytti luottamusta organisaation toimijoiden johdonmukaiseen johdon päätöksiä toteuttavaan operaatioiden läpivientiin.

\section{JOHTOPÄÄTÖKSET}

Tapaustutkimuksen luonteen mukaisesti narratiivinen tutkimus tuo esille muutoksen ja luottamuksen kehittymisen vaiheittaisen luonteen. Luottamusta ja sen luonteen kehittymistä tarkasteltiin ei-henkilöityvänä voimavarana vähittäistavarakaupan ketjuliiketoiminnan johtamisessa. Tutkimusaineiston hankinta ja analyysi käsittää kaupan alan organisaation johtamisjärjestelmän uudistamisen implementointi- ja vahvistamisvaiheet, joiden kautta luottamuksen luonnetta peilataan lähtötilanteeseen. 
Taulukko 1. Johtaminen ja luottamuksen kehittyminen johtamisjärjestelmän lähtö-, implementointi- ja vahvistamisvaiheissa (mukaillen Malkamäki 2017, 124)

\begin{tabular}{|c|c|c|c|}
\hline & $\begin{array}{l}\text { Lähtötilanne } \\
\text { 2003-2008 }\end{array}$ & $\begin{array}{l}\text { Implementointivaihe } \\
\text { 2009-2010 }\end{array}$ & $\begin{array}{l}\text { Vahvistamisvaihe } \\
\text { 2011-2013 } \\
\end{array}$ \\
\hline $\begin{array}{l}\text { Johtaminen ja } \\
\text { johtajuus }\end{array}$ & $\begin{array}{l}\text { Tulosjohtajuus } \\
\text { Myyntihakuisuus }\end{array}$ & $\begin{array}{l}\text { Läpinäkyvyys } \\
\text { johtamisessa } \\
\text { Prosessijohtamisen malli }\end{array}$ & $\begin{array}{l}\text { Tehtäväjohtajuus } \\
\text { Määrätietoinen linjassa } \\
\text { pysyminen }\end{array}$ \\
\hline $\begin{array}{c}\text { Toiminnallisten } \\
\text { organisaatio- } \\
\text { yksiköiden roolit } \\
\text { ja työn jako } \\
\end{array}$ & $\begin{array}{l}\text { Roolit ja toimenkuvat osin } \\
\text { päällekkäisiä } \\
\text { Päätöksenteko osin jaettua }\end{array}$ & $\begin{array}{l}\text { Toiminnallisten yksiköiden } \\
\text { selkeä työnjako ja } \\
\text { roolittaminen }\end{array}$ & \begin{tabular}{|l|} 
Yhteiseen tavoitteeseen \\
tähtäävä toiminnan \\
suunnittelu, päätöksenteko ja \\
toimeenpano eriytynyt rooli- \\
ja toimenkuvakohtaisesti \\
\end{tabular} \\
\hline $\begin{array}{l}\text { Päätöksenteko- } \\
\text { menettely } \\
\text { (johtamismalli) }\end{array}$ & $\begin{array}{l}\text { Toiminnallisten yksiköiden } \\
\text { tehtävärajaukset ja toimenkuvat } \\
\text { osin epämääräiset } \\
\text { Henkilökohtaisiin näyttöihin } \\
\text { perustuvia oman toimen ohella } \\
\text {-tehtäviä } \\
\text { Asiantuntijuuteen ja osaamiseen } \\
\text { perustuvat suunnitteluryhmät } \\
\text { muodostavat eräänlaisen piilo- } \\
\text { organisaation } \\
\end{array}$ & $\begin{array}{l}\text { Päätöksen tekemisen } \\
\text { oikeudet ja } \\
\text { valtuudet rajataan ja } \\
\text { tarkennetaan rooli- ja } \\
\text { toimenkuvakohtaisesti } \\
\\
\text { Liiketoiminnan } \\
\text { kannalta olennaiset } \\
\text { menettelyt kuvataan ja } \\
\text { dokumentoidaan }\end{array}$ & $\begin{array}{l}\text { Ketjuyksikön ohjauksen } \\
\text { vahvistuminen ja } \\
\text { tarkentuminen } \\
\text { Päätöksenteko oman } \\
\text { toimenkuvan osalta hierarkian } \\
\text { mukaan }\end{array}$ \\
\hline $\begin{array}{l}\text { Tavoiteasetanta- } \\
\text { ja } \\
\text { seuranta- } \\
\text { menettelyt } \\
\text { Suoritustaso }\end{array}$ & $\begin{array}{l}\text { Yksikkökohtainen tavoiteasetanta } \\
\text { vaihtelee } \\
\text { Ei ketjutason systemaattista ohjaus- } \\
\text { ja valvontamenettelyä } \\
\rightarrow \\
\text { merkittäviä suoritustason } \\
\text { vaihteluvälejä }\end{array}$ & \begin{tabular}{|l|} 
Ketjutasolla asetetut \\
tavoitteet ja seuranta \\
Mittariston uudistaminen \\
Menettelyt kuvataan ja \\
niiden noudattamista \\
valvontaan $\rightarrow$ \\
Yhdenmukaisempi \\
liikkeenjohdollinen ote $\rightarrow$ \\
toiminta tasalaatuistuu \\
\end{tabular} & $\begin{array}{l}\text { Ketjutason tavoiteasetantaa ja } \\
\text { seurantaa tarkennetaan } \rightarrow \\
\text { suorituksen johtaminen } \\
\text { yhdenmukaistuu }\end{array}$ \\
\hline $\begin{array}{l}\text { Toiminnan } \\
\text { kehittäminen }\end{array}$ & $\begin{array}{l}\text { Parhaiden käytäntöjen läpivienti } \\
\text { ketjutasolla vaihtelee } \\
\text { Ei ketjutason tarkkaa ohjeistusta } \\
\text { ja valvontaa }\end{array}$ & \begin{tabular}{|l|} 
Yhdenmukaiset, \\
dokumentoidut odotukset \\
Ketju- ja yksikkötason \\
toiminnan kehittäminen, \\
johtaminen ja valvonta \\
johdonmukaista ja \\
systemaattista
\end{tabular} & $\begin{array}{l}\text { Toiminnan kehittäminen } \\
\text { yksikkötasolla tulee olla } \\
\text { ketjutasolla asetettujen } \\
\text { tavoitteiden ja odotusten } \\
\text { mukaista } \\
\text { Ohjeistuksen mukainen } \\
\text { suoritustaso }\end{array}$ \\
\hline $\begin{array}{l}\text { Viestintä- } \\
\text { ja } \\
\text { vuorovaikutus- } \\
\text { menettelyt }\end{array}$ & $\begin{array}{l}\text { Ketjutason kokous- ja face-to-face } \\
\text { työryhmäfoorumit } \\
\text { Henkilökohtaiset suhteet ja } \\
\text { puhelinkeskustelut } \rightarrow \text { vaikuttamisen } \\
\text { mahdollisuus vaihtelee } \\
\text { aktiivisuuden ja näyttöjen mukaan }\end{array}$ & $\begin{array}{l}\text { Sähköisiä viestintä- ja } \\
\text { vuorovaikutusmenettelyitä } \\
\text { kehitetään, } \\
\text { yhdenmukaistetaan ja } \\
\text { kuvataan }\end{array}$ & \begin{tabular}{|l} 
Hankinta- ja \\
tavarataloyksiöiden yhteistyö, \\
viestintä ja vuorovaikutus \\
pääosin sähköistä, sisäisessä \\
verkossa tapahtuvaa \\
yksisuuntaista viestintää
\end{tabular} \\
\hline Luottamus & \begin{tabular}{|l|}
$\begin{array}{l}\text { Luottamus toiminnallisten } \\
\text { yksiköiden välillä vaihtelee } \\
\text { tulosyksiköittäin }\end{array}$ \\
Luottamus henkilöiden välistä \\
Luottamus perustuu tuntemiseen ja \\
henkilökohtaiseen kompetenssiin
\end{tabular} & $\begin{array}{l}\text { Luottamus toiminnallisten } \\
\text { yksiköiden välillä } \\
\text { vahvistuu } \\
\overrightarrow{\text { luottamus organisaatioon }}\end{array}$ & $\begin{array}{l}\text { Luottamus yksiköiden ja } \\
\text { toimijoiden välillä vahvasti } \\
\text { rooliin ja toimenkuvaan } \\
\text { perustuvaa }\end{array}$ \\
\hline
\end{tabular}




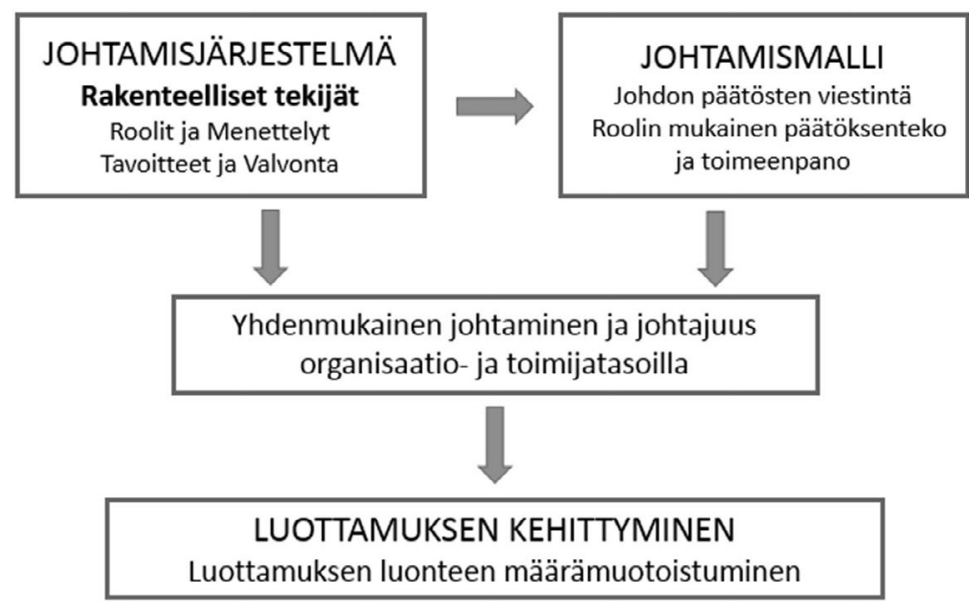

Kuvio 2. Empiiristen tulosten yhteenveto: uudistettuun johtamisjärjestelmään perustuva johtaminen ja luottamuksen luonteen määrämuotoistuminen (Malkamäki 2017, 137)

Selkeä johtamisjärjestelmä näyttäytyy muutoksen johtamisen työvälineenä. Johtamisjärjestelmän ohjauksen ja valvonnan säätelymekanismit muodostavat perustan ja perusteen roolin mukaiselle johtamiselle ja ei-henkilöityvän luottamuksen ansainnalle. Yhteinen tavoite ja työnjako sekä yhteinen ymmärrys roolin mukaisista oikeuksista ja velvollisuuksista selkeyttävät johtamista, sillä johtamisjärjestelmä legitimoi johtamiskäytännöt ja menettelyt. Kun toiminta perustuu läpinäkyviin yhdenmukaisiin odotuksiin ja johdonmukaisiin johtamismenettelyihin, muodostaa se vahvan johtamisen perustan. Samalla se synnyttää luottamusta niin organisaation johtoon kuin organisaatioyksiköiden ja toimijoiden välille. Siten se toimii kilpailukykyä vahvistavana voimavarana.

Vahvaan ohjeistukseen perustuvassa johtamiskulttuurissa luottamus näyttää saavan määrämuotoisen, ei-henkilöityvän luonteen. Luottamuksen perusta on organisaation rakenteellisissa tekijöissä, jotka ohjaavat sosiaalista kanssakäymistä, päätöksentekoa ja toimeenpanoa (kuvio 2). Käsitteellisesti tarkastellen tehtäväkohtainen, henkilöstä riippumattomaton, yhdenmukaisuuden ja määrämuotoisuuden odotuksia painottava luottamus näyttäytyy luonteeltaan institutionaalisena (vrt. Zucker 1986). Luottamuksen luonteen institutionalisoituminen ilmeni tapausorganisaatiossa siten, että luotta- mus ei perustunut niinkään tuntemiseen ja toimijan henkilökohtaisiin ominaispiirteisiin sekä ammatilliseen kompetenssiin, vaan suorituksen johtamiseen roolin ja toimenkuvien mukaisesti. Nooteboom ym. (1997) ovatkin todenneet, että kun johtamista qua persona ohjataan ja rajoitetaan organisaation rooleilla ja linjauksilla, roolit määrittävät henkilöiden välistä toimintaa organisaation roolien mukaisesti.

Uudessa järjestelmässä johtaminen ja luottamuksen ansainta perustuivat roolin ja määriteltyjen johtamismenettelyiden mukaiseen suorituksen johtamiseen. Rooliperusteinen luottamus ei välttämättä edellytä henkilökohtaisiin suhteisiin ja historiatietoon perustuvaa henkilökohtaista tuntemista ja prosessinomaista luottamuksen syvenevää kehittymistä toisin kuin Lewicki ja Bunker (1996) ovat tuoneet esiin. Sen sijaan se perustuu ensisijaisesti yksilön roolin ja toimenkuvan mukaista kyvykkyyttä ja suoritustasoa osoittaviin näyttöihin (vrt. Mayer et al. 1995). Tähän perustuen luottamusta voidaan luonnehtia johtamiskulttuuri- ja johtamisjärjestelmäsidonnaiseksi ilmiöksi (Malkamäki 2017). Johtamiskulttuurin muutoksen myötä organisaatiossa siirryttiin aikaisemman johtamisjärjestelmän aikakauden itsenäistä päätöksentekoa sallineesta tulosjohtajuuden aikakaudesta tehtäväjohtajuuteen. Samalla kun luottamuksenarvoisuuden perusteet muuttuivat tehtäväkohtai- 
siksi, myös luottamus kehittyi ei-henkilöityvän luottamuksen suuntaan, rooli- ja tehtäväkohtaiseksi tehtäväluottamukseksi.

Johtamisjärjestelmä toimii luottamuksen lähteenä ja vahvistajana (Zucker 1986). Tässä artikkelissa esitetyn tulkinnan mukaan johtamisjärjestelmä ohjaa yrityksen strategian mukaista operatiivista liiketoiminnan johtamista ja käyttäytymistä organisaatiossa. Johtamisjärjestelmään sisältyvät yhdenmukaiset valvonta- ja seurantamenettelyt toimivat luottamusta rakentavina ja vahvistavina tekijöinä yhteistyöprosesseissa silloin, kun ne tuottavat ennustettavuutta, tasalaatuisuutta ja tehokkuutta.

Tutkimus implikoi, että selkeä johtamisjärjestelmä on yhteistyön sekä luottamuksen ja luottamuksenarvoisuuden dynamo (vrt. Kramer 1999) ja linkki. Se on johdon työväline ohjata työyhteisön johtamista, yhteistyötä ja osaamista, joka tuottaa luottamusta organisaatioon ja toimijoiden välille. Lisäksi johtamisjärjestelmä korvaa tiedon jakamisen ja ohjauksen sekä valvonnan tehtävää, joka perinteisesti on ollut johdon ja lähiesimiehen tehtäväaluetta. Siten se poistaa tai vähentää usein keskusteluissa esille nousevaa, valtakysymyksenä koettua tiedon asymmetriaa esimiesten ja alaisten välillä.

\section{Tutkimuksen rajoitukset ja jatkotutkimusaiheet}

Tässä esitetty tutkimusaineisto käsittää joitakin rajoitteita. Tutkimukseen valittu laadullinen menetelmä tavoittaa rajallisesti todellisen elämän monimuotoisuutta ja laajuutta. Esimerkiksi tässä tapaustutkimuksessa saadaan esille vain tutkittavien kokemukset ja näkemykset. Siksi mitä ilmeisimmin laadullisen ja määrällisen tutkimusmetodologian yhdistäminen voisi tuottaa tutkimustiedolle lisäarvoa, validiteettia ja yleistettävyyttä, vaikka luottamus on hyvin kontekstisidonnainen ilmiö eikä kovin helposti kvantifioitavissa (Seppänen ym. 2007).

Tutkimus (Malkamäki 2017) tuotti useita luottamuksen ja johtamisen linkittäviä jatkotutkimusaiheita, sillä digitalisaatio ja robotiikka lisäävät tarvetta kehittää johtamista ja johtamisjärjestelmiä. Ensinnäkin, miten johtamisen eri moodit, digitaalisuus ja kasvokkain kohtaamiset vahvistavat luottamusta niin organisaation sisäisissä kuin organisaation ulkoisissa asiakaspalve- lusuhteissa. Toiseksi, miten robotiikan koetaan vaikuttavan työyhteisöissä niin henkilöiden, tiimien kuin organisaatiotason suhteissa (ks. Savolainen 2016). Kolmanneksi, olisi tärkeää selvittää johtamisjärjestelmän ja luottamuksen yhteyttä ja tuottaa sellaista tietoa, jota voidaan hyödyntää yli toimialojen ja niin julkisella kuin yksityisellä sektorilla. Siksi on syytä tarkastella missä määrin ja millä tavoin johtamisjärjestelmään perustuvat digitaaliset mahdollisuudet korvaavat tiedonjakamisen ja ohjauksen tehtäviä ja miten tätä vahvistetaan henkilöiden välisissä kohtaamisissa.

\section{LÄHTEET}

Avolio, B.J., Kahai, S., Dodge, G. E. (2001). E-leadership: Implications for Theory, Research, and Practice. Leadership Quarterly, 11(4), 615668.

Bachmann, R. (2003). The Trust Process in Organizations Empirical Studies of the Determinants and the Process of Trust Development. Teoksessa B. Nooteboom \& F. Six, (Eds.) Empirical Studies of the Determinants and the Process of Trust Development. Cheltenham, UK. Edward Elgar, 58-74.

Bachmann, R. (2011). At the crossroads: Future directions in trust research. Journal of Trust Research, 1(2), 213-230.

Berger, W. \& Luckmann, T. (1994). Todellisuuden sosiaalinen rakentuminen: Tiedonsosiologinen tutkielma. (The Social Consruction of Reality, 1966). Suomentanut Vesa Raiskila. Helsinki: Gaudeamus 1994.

Bijlsma-Frankema, K (2001) On managing cultural integration and cultural change processes in mergers and acquisitions. Journal of European Industrial Training 25(2-4): 192-207.

Bijlsma-Frankema, K. \& Koopman, P. (2004). The oxymoron of control in an era of globalisation: Vulnerabilities of a Mega Myth. Journal of Managerial Psychology, 19 (3), 204-217.

Bogdan, R.C. \& Biklen, S.K. (1992). Qualitative Research for Education. An Introduction to Theory and Methods. Boston: Allyn and Bacon.

Brandsen T. \& Karre, P.M. (2011). Hybrid Organizations: No Cause for Concern? International Journal of Public Administration, 34(13), 827-836.

Burke, C.S., Sims, D.E., Lazzara, E.H. \& Salas, E. (2007). Trust in Leadership: A multilevel review and integration. The Leadership Quarterly, 18(6), 606-632 
Cardinal, L.B., Sitkin, S.B. \& Long, C.P. (2004). Balancing and Rebalancing in the Creation and Evolution of Organizational Control. Organization Science, 15(4), 411-431.

Creed, W.E.D. \& Miles, R. E. (1996). Trust in organizations, a conceptual framework. Teoksessa R. M. Kramer \& T. R. Tyler (Eds.) Trust in Organizations: Frontiers of Theory and Research. Thousand Oaks, California: Sage Publications, 16-39.

Das, T.K. \& Teng, B.S. (2001). Trust, Control, and Risk in Strategic Alliances: An Integrated Framework. Organization Studies, 22(2), 251283.

Dietz, G. (2011). Going back to the source: Why do people trust each other? Journal of Trust Research, 1(2), 215-222.

Eriksson, P. \& Kovalainen, A. (2016). Qualitative Methods in Business Research. 2. Painos. London: Sage Publications.

Eskola, J. \& Suoranta, J. (2008). Johdatus laadulliseen tutkimukseen, 8 p. Tampere: Vastapaino.

Elsbach, K. \& Kramer, R.M. (1996). Members' Responses to Organizational Identity Threats: Encountering and Countering the Business Week Rankings. Administrative Science Quarterly, 41(3), 442-476.

Fukuyama, F. (1995). Trust: The Social Virtues and the Creation of Prosperity. New York: Free Press.

Fulmer, C.A. \& Gelfand, M.J. (2012). At What Level (and in Whom) We Trust: Trust across Multiple Organizational Levels. Journal of Management, 38(4), 1167-1230.

Giddens, A. (1990). The Consequences of Modernity. Stanford: Stanford University Press.

Gillespie, N. \& Mann, L. (2004). Transformational leadership and shared values: The building blocks of trust. Journal of Managerial Psychology, 19(6), 588-607.

Goold, M. \& Gampbell, A. (1987). Strategies and Styles: the role of center in managing diversified corporations. Oxford: Basil Blackwell.

Hardy, C., Phillips, N. \& Lawrence, T. (1998). Distinguishing Trust and Power. Interorganizational Relations: Forms and Facades of Trust. In C. Teoksessa Lane \& R. Bachmann (Eds.) Trust Within and Between Organizations: Conceptual Issues and Empirical Applications. New York: Oxford University Press, 64-87.

Ikonen, M. (2015). Esimies-alaissuhteen luottamuksen kehittyminen vuorovaikutuksessa rakentuvana prosessina. Puheviestinnän vuosikirja Prologi 2015.

Ilmonen, K. (2000). Sosiaalinen pääoma: käsite ja sen ongelmallisuus. Teoksessa K. Ilmonen (toim.) Sosiaalinen pääoma ja luottamus. Jyväskylä: SoPhi, Jyväskylän yliopisto, 9-38.

Jagd, S. \& Fuglsang, L. (2016). Studying trust as process within and between organizations. Teoksessa S. Jagd \& L. Fuglsang (Eds.) Trust, Organizations and Social Interaction. Cheltenhamn, UK: Edward Elgar.

Kamensky, M. (2008). Strateginen johtaminen: menestyksen timantti. Helsinki: Talentum.

Kaptein, M. (2008). Developing and testing a measure for the ethical culture of organizations: the corporate ethical virtues model. Journal of Organizational Behavior, 29, 923-947.

Kramer, R.M. (1999). Trust and distrust in organizations: Emerging Perspectives, Enduring Questions. Annual Review of Psychology, 50(2), 569-598.

Laaksonen, H. (2008). Luottamukseen perustuvan voimistavan johtamisen prosessimalli ja työyhteisön hyvinvointi. Väitöskirja. Acta Wasaensia no 187. Vaasan yliopisto, Vaasa.

Laamanen, K. \& Tinnilä, M. (2009). Prosessijohtamisen käsitteet - Terms and concepts in business process management (4th ed.). Espoo: Teknologiateollisuus Oy/Teknologiainfo Teknova Oy.

Lane, C. (1998). Introduction: Theories and Issues in the Study of Trust. Teoksessa C. Lane \& R. Bachmann (Eds.) Trust Within and Between Organizations. Oxford: Oxford University Press, $1-30$.

Limerick, D. \& Cunnington, B. (1993). Managing the New Organization: a blueprint for networks and strategic alliances. San Francisco: JosseyBass Publishers.

Long, C. \& Sitkin, S. (2006). Trust in the balance: how managers integrate trust-building and task control. Teoksessa R. Bachmann \& A. Zaheer (Eds.) Handbook of trust research. Cheltenham: Edward Elgar, 87-106.

McEvily, B., Perrone, V. \& Zaheer, A. (2003). Trust as an Organizing Principle. Organization Science, 14(1), 91-103.

Malkamäki, K. (2010). Luottamuksen rakentuminen sisäisessä asiakkuudessa: tapaustutkimus kaupan alan yrityksen kahdesta toimintayksiköstä. Pro gradu -tutkielma. Itä-Suomen yliopisto, Joensuu.

Malkamäki, K. (2017). Luottamuksen kehittyminen ja johtamisjärjestelmää koskeva uudistus - tapaustutkimus kaupan alan organisaatiosta. Väitöskirja. Yhteiskuntatieteiden ja kauppatieteiden tiedekunta, No 145. Itä-Suomen yliopisto, Joensuu.

Mayer, R. C. \& Davis J. H. \& Schoorman F. D. (1995). An Integrative Model of Organisational 
Trust. Academy of Management Review, Vol. 20. No. 3, 709-734.

Mintzberg, H. (1979). The Structuring of Organizations. Englewood Cliffs, NJ: PrenticeHall.

Mitronen, L. (2002). Hybridiorganisaation johtaminen - tapaustutkimus kaupan verkosto-organisaatiosta. Väitöskirja. Acta Universitatis Tamperensis 877. Tampereen yliopisto, Tampere.

Morgan, D. E. \& Zeffane, R. (2003). Employee involvement, organizational change and trust in management. International Journal of Human Resource Management 14 (1), 55-75.

Mäkipeska, M. \& Niemelä, T. (2005). Haasteena luottamus - työyhteisön sosiaalinen pääoma. Helsinki: Edita Publishing Oy.

Möllering, G. (2005). The Trust/Control Duality. An Integrative Perspective on Positive Expectations of Others, International Sociology, 20(3), 283-305.

Nooteboom, B., Berger, H. \& Nooderhaven, N. G. (1997). Effect of Trust and Governance on Relational Risk. Academy of Management Journal, 40(2), 308-338.

Payne, A. \& Frow, P. (2005). A Strategic Framework for Customer Relationship Management. Journal of Marketing, 69(10), 167-176.

Puusa, A. \& Juuti, P. (2011). Tieteenfilosofisista kysymyksistä laadullisen tutkimuksen näkökulmasta. Teoksessa A. Puusa \& P. Juuti (toim.) Menetelmäviidakon raivaajat. Perusteita laadullisen tutkimuslähestymistavan valintaan. Vantaa: Hansaprint, 11-27.

Rao, H., Monin, P. \& Durand, R. (2003). Institutional Change in Toque Ville: Nouvelle Cuisine as an Identity Movement in French Gastronomy. American Journal of Sociology, 108(4), 795-843.

Riessman, C.K. (1993). Narrative analysis. Newbury Park, CA, Sage.

Rousseau, D.M., Sitkin, S.B., Burt, R.S. \& Camerer, C. (1998). Not so different after all: A cross-discipline view of trust. Academy of Management Review, 23(3), 393-404.

Savolainen Taina (2016) Luottamus - digijohtamisen voimavara ja taitohaaste. Ratkes-lehti No 1, s. 23-31.

Savolainen, T. \& Ikonen, M. (2016). Process Dynamics of Trust Development: Exploring and Illustrating Emergence in the Team Context. Teoksessa Jagd, S. \& Fuglsagn, L. (Eds.) Trust, Organisations and Interaction: Studying Trust as Process within and between Organizations. Cheltenham, UK: Edward Elgar Publishing, 12, 231-256.
Savolainen, T. (2014). Trust-Building in e-Leadership: A Case Study of Leaders' Challenges and Skills in Technology-Mediated Interaction. Journal of Global Business Issues, Vol 8, Iss. 2 (Fall/Winter), pp. 45-56.

Savolainen, T. (2011). Luottamusjohtajuus inhimillisen pääoman uudistamisessa. Teoksessa Puusa, A. \& Reijonen, H. (toim.) Aineeton pääoma organisaation voimavarana. UNIPress. pp. 117-141.

Schoorman, F.D., Mayer, R.C. \& Davis, J.H. (2007). An integrative model of organizational trust: Past, present, and future. Academy of Management Review, 32(2), 344-354.

Schnackenberg, A. K. \& Tomlinson, E. C. (2016) Organizational Transparency: A New Perspective on Managing Trust in Organization-Stakeholder Relationships. Journal of Management 42(7), 1784-1810.

Sitkin, S.B. (1995) 'On the positive effect of legalization on trust'. Research on Negotiations in Organizations, Vol. 5, 185-217.

Sitkin, S.B. \& George, E. (2005). Managerial TrustBuilding Through the Use of Legitimating Formal and Informal Control Mechanisms. International Sociology, 20(3), 307-338.

Sverdrup, T. \& Stensaker, I. (2018). Restoring trust in the context of strategic change. Strategic Organization, Vol. 16(4) 401-428.

Sztompka, P. (1999). Trust: A Sociological Theory. United Kingdom: Cambridge University Press.

Sørensen, O. H., Hasle P \& Pejtersen J. H. (2011). Trust relations in management of change. Scandinavian Journal of Management 2011, Dec, Vol. 27(4), 389-404.

Vanhala, M. (2011) Impersonal Trust within the Organization: What, how and why? Väitöskirja. Lappeenrannan teknillinen yliopisto, 445.

Welter, F. (2012). All you need is trust? A critical review of the trust and entrepreneurship literature. International Small Business Journal, 30(3), 193-212.

Whitener, E.M., Brodt, S.E., Korsgaard, M.A. \& Werner, J.M. (1998). Managers as initiators of trust: An exchange relationship framework for understanding managerial trustworthy behavior. Academy of Management Review, 23, 513530.

Yukl, G. (2010). Leadership in organizations (7th ed.). New Jersey. Prentice Hall.

Zucker, L.G. (1986). Production of trust: Institutional sources of economic structure, 1840-1920. Research in Organizational Behavior, $8,53-111$. 